\title{
Haematological and Genotoxicity Evaluations of Phytochemical Compounds from n-Hexane Extract of Uvaria chamae Stem on Selected Organs in Mice
}

\author{
Oladipupo R. Akolade ${ }^{1}$, Alaribe S. Chinwe ${ }^{{ }^{*}}$, Balogun T. Olalekan ${ }^{1}$, Akere T. Halima ${ }^{1}$, Ayanda \\ A. Fatima $^{1}$, Toye T. Emuejevoke ${ }^{2}$ and Coke A.B. Herbert ${ }^{1}$
}

${ }^{1}$ Department of Pharmaceutical Chemistry, Faculty of Pharmacy, University of Lagos, Nigeria.
${ }^{2}$ Biologix Support Services, Anthony Village, Maryland, Ikeja, Lagos

Received 13th Apr.2018, Accepted $6^{\text {th }}$ Jun. 2018

DOI: 10.2478/ast-2018-0012

*Corresponding author

C.S. Alaribe email: aalaribe56@gmail.com salaribe@unilag.edu.ng

Tel: $+234-8037263962$

\begin{abstract}
Phytochemical constituents of plants extracts have been well investigated as leads for drug discovery and development. However, aside their immense medicinal properties, their safety is also of paramount importance, therefore evaluating the toxicity of plants extracts and their phytochemicals is an important aspect of quality measures to meet the requirements for consumption. This study was done to identify the volatile phytochemical compounds present in n-hexane extract of Uvaria chamae stems (UCSH) with the aid of gas chromatography-mass spectrometry (GC-MS) and to evaluate the effects of this non-polar extract on DNA using diphenylamine (DPA) and agarose gel electrophoresis assays, also to investigate the haematological parameters using an auto Haematology Analyzer.The GC-MS analysis of UCSH identified some compounds which include; squalene, lupeol, stigmasterol, $\beta$-sitosterol, and Benzyl benzoate with excellent medicinal properties. Genotoxicity assays results showed significant reductions in DNA fragmentation in liver and testis cells of mice as against the DNA biomarker and vehicle control group. Haematological results showed significant increase in white blood cells (WBC), red blood cell (RBC), platelets (PLT) and lymphocytes (LYMP) but significant reduction in mean corpuscular - volume (MCV), haemoglobin $(\mathrm{MCH})$, and haemoglobin concentration (MCHC). The present study showed that the phytochemicals present in the n-Hexane extract of Uvaria chamae stems may play protective role in the genomic DNA of liver and testis tissues and also may induce hematological changes which may enhance the immune system.
\end{abstract}

Keywords:Uvaria chamae; Liver; Testis; Genotoxicity; Haematology. 


\subsection{Introduction}

Plants have an expansive history in traditional medicine and have contributed invaluably to human health care. The World Health Organization (WHO) estimated that up to $80 \%$ of the world's population relies on traditional medicines mostly derived from plants for some aspect of primary health care (Farnsworth et al., 1985). The medicinal properties of many plants extracts have been investigated and documented while a large number still remains underutilized. These scientific evidences have contributed to the increasing usage of plants extracts as alternative medicines all over the world. Volatile compounds are examples of such plants extracts containing mixtures of non-polar lipophilic phytochemicals. Due to their chemical properties they are widely used as fragrances and additives in cosmetic and food industries. They are also used for medicinal purposes and have been documented to have a plethora of pharmacologic properties such as antimicrobial, antioxidant, antiinflammatory, and antispasmodic properties (Tognolini et al., 2006).

Despite the wide use of plants extracts as alternative medicines, it is important to note that such preparations are often used without adequate information on their toxic effects as regards dosage. This inadequacy has limited their full acceptance into international health market. For this reason, it is important to subject plants extracts to toxicity tests in order to investigate the potential health risks from their consumption, especially over a period of time. Genotoxicity analysis involves the assessment of the degree to which a substance is toxic to genetic materials and it is vital as damage to them has been implicated in the pathogenesis of many diseases, including cancer. Genotoxicity study helps in detecting substances capable of causing DNA damage and/or protecting DNA, and also understanding the potential biological consequences (Uhl, et al., 2003). On the other hand, investigation of the possible effects of phytochemicals on the hematological parameter of animals is also an important tool in toxicity studies.

The biological properties of plants are by virtue of their phytochemical constituents, thus the analysis of these phytochemicals may help in identifying the compounds that exert the different biological actions demonstrated by a certain plant. Uvaria chamae (Annonaceae), also known as bush banana or finger rootis a climbing shrub that grows to a height of about $3.6-4.5 \mathrm{~m}$ and is found in the tropical wet and dry forests of West and Central Africa (Moses et al., 2013). All parts of the plants are fragrant and the plant has both medicinal and nutritional values. Extracts of different parts of $U$. chamae are used in ethnomedicine for treating many ailments; including diarrhea, gastroenteritis, inflamed gums, wounds, dysentery, sore throats, sickle cell disease, stroke, and cancer.

The leaf extracts of $U$. chamae have been reported to possess antibacterial (Oluremi et al., 2010), antifungal (Okwuosa et al., 2012), antispasmodic, anti-trypanosomal and anti-inflammatory (Adelodun et al. 2013) properties. The roots of the plant have been reported to demonstrate antibacterial, antioxidant (Kone et al., 2015), anti-inflammatory, oxytocic (Okwu and Iroabuchi, 2009) and anti-sickling (Thierry et al., 2012) activities. Two benzyldihydrochalcones; chamuvaritin and chamuvarin have been isolated from the roots of U. chamae (Uwaifo and Bababunmi, 1984).

Fewer studies have been done on the stems of $U$. chamae. In this study we focused on characterizing the phytochemical constituents present in $n$ Hexane extract of $U$. chamae stem (UCSH) and also to evaluate its effects on the hematological parameters as well as on the genetic materials of selected organs in mice.

\subsection{Materials and Methods}

\subsection{Chemicals and reagents}

$n$-Hexane (BDH), Phosphate buffer saline, normal saline, tween 80, sulphuric acid, trichloroacetic acid, glacial acetic acid, diphenylamine, and all other reagents used were of analytical grade.

\subsection{Collection of plant materials}

Fresh stems of $U$. chamae were obtained in Sango-ota, Ogun State, identified and authenticated by Mr Oyebanji of the Department of Botany, University of Lagos, Akoka. Specimen of plant material was deposited at the same University herbarium with voucher number; LUH: 7664 allotted to it.

\subsection{Extraction of plant materials}

The freshly collected stems of $U$. chamae were air dried and ground into fine powder. Approximately $100 \mathrm{~g}$ of the finely pulverized stems were extracted with $1.0 \mathrm{~L}$ of $n$-Hexane by maceration method at room temperature for $72 \mathrm{~h}$. This process was carried out three consecutive times. The extracts were collected, combined and concentrated under reduced pressure using rotatory evaporator to yield $U$. chamae stems $n$ hexane extract (UCSH).

\subsection{Gas chromatography-mass spectrometry (GC-MS) analysis}

Chromatographic separation and identification of compounds were carried out on UCSH using Gas Chromatography (GC) hyphenated Mass Spectroscopy (MS)-Agilent- equipped with HP-5MS capillary column of Length-:30.0 m, Diameter-: $0.25 \mathrm{~mm}$, film thickness- : $0.25 \mu \mathrm{m}$ composed of $100 \%$ Dimethyl poly-siloxane. The GC-MS had an electron ionization system with ionization energy of $70 \mathrm{eV}$, and an ion source temperature of $230^{\circ} \mathrm{C}$. Helium gas was used as a carrier gas at a flow rate of $2.0 \mathrm{~mL} / \mathrm{min}$. The injector and the interface temperature were set at $280{ }^{\circ} \mathrm{C}$ and $350{ }^{\circ} \mathrm{C}$ respectively. The oven temperature was programmed as $45^{\circ} \mathrm{C}(5 \mathrm{~min})$ to $325^{\circ} \mathrm{C}(10 \mathrm{~min})$ at an increasing rate of $15^{\circ} \mathrm{C} / \mathrm{min}$. The total $\mathrm{GC}$ run time was $35 \mathrm{~min}$. Interpretations of mass spectra of separated components were identified relative to the mass spectra of compounds in the National Institute of Standards and Technology (NIST) library [see supporting Document for spectra].

\subsection{Genotoxicity assays \\ 2.5.1 Experimental animals}

Male albino mice of average weight, $22 \mathrm{~g}$ and obtained from animal facility centre, College of Medicine, University of Lagos were used for this study. The mice were administered standard mice diet and water ad libitum for two weeks and allowed to acclimatise in a well-ventilated animal house for $14 \mathrm{~d}$. Handling of animals was done in accordance with international acceptable guidelines and approval from College of Medicine, University of Lagos Health Research Ethics Committee with reference number; CMUL/HREC/03/18/341. 


\subsubsection{Experimental protocols}

The toxicity study was done according to OECD (2008) limit test (with some modifications).

The animals were divided into three groups; 1,2 and 3 after acclimatization. The test group, group 3 was orally administered 50 $\mathrm{mg} / \mathrm{kg}$ dose of UCSH. The control groups, groups 1 and 2 were orally administered normal saline (negative control) and 3\% tween 80-normal saline (vehicle control) respectively. The animals were observed within $48 \mathrm{~h}$ for any behavioural change. At the end of this period, blood samples were collected by retro-orbital puncture using capillary tube into EDTA bottles, and the animals were sacrificed by cervical dislocation and their liver and testis were harvested for genotoxic analysis.

\subsubsection{Estimation of fragmented DNA by diphenylamine (DPA assay)}

The colorimetric estimation of DNA content was done according to Gibb et al. (1997). Approximately $30 \mathrm{mg}$ of each harvested organ (liver and testis) was lysed in $0.5 \mathrm{~mL}$ lysis buffer and centrifuged at 10000 r.p.m for $20 \mathrm{~min}$ at $4{ }^{\circ} \mathrm{C}$. The pellets were re-suspended in $0.5 \mathrm{~mL}$ of lysis buffer. To the pellets (P) and supernatant (S), $1.5 \mathrm{~mL}$ of $10 \%$ trichloroacetic acid (TCA) was added and incubated at $4{ }^{\circ} \mathrm{C}$ for $10 \mathrm{~min}$. Both supernatant and the pellet were used for DPA assay after acid extraction of DNA. The proportion of fragmented DNA (\%) was expressed at $600 \mathrm{~nm}$ using the formula:

\section{$\%$ DNA fragmentation $=$ $\frac{\text { A of fragmented DNA }(S)}{\text { A of fragmented DNA }(S)+A \text { of intact DNA }(P)} \times 100$}

Where $\mathbf{A}$ is the absorbance of the sample

\subsubsection{Qualitative Assessment of DNA Fragmentation by Gel Electrophoresis}

Genomic DNA fragmentation was assessed using agarose gel electrophoresis. Genomic DNA was isolated from liver and testis samples according to Feki et al. (2015) with some modifications. Approximately $20 \mathrm{mg}$ of the mice liver and testis tissues consecutively, were washed with $100 \mu \mathrm{L}$ of phosphate buffer saline (PBS) followed by addition of $200 \mu \mathrm{L}$ lysis buffer and $10 \mu \mathrm{L}$ proteinase $\mathrm{K}$. The content was mixed thoroughly by vortexing followed by heating in the water bath at $55^{\circ} \mathrm{C}$ for $2-3 \mathrm{~h}$.

Equal volumes $(100 \mu \mathrm{L})$ of tris-EDTA (TE) buffer and $2 \%$ sodium dodecyl sulphate (SDS) were added, followed by mixing and vortexing. The resulting solution was centrifuged at $12,000 \mathrm{~g}$ for $1 \mathrm{~min}$. Equal

volume of extracted DNA $(20 \mu \mathrm{L})$ was loaded on $2 \%$ agarose gel, stained with ethidium-bromide DNA dye and electrophoresed at 40 volts for 2 hours in X 0.5 Tris/Acetate/EDTA (TAE) buffer. DNA fragments were visualised and photographed by exposing the gel to ultraviolet (UV) trans-illumination.

\subsubsection{Determination of haematological parameters}

Haematological parameters viz., haemoglobin concentration (HB), packed cell volume (PCV), red blood cell (RBC) count, white blood cell (WBC), platelets (PLT), lymphocytes (LYMP), neutrophils (NEU), monocytes (MID), mean corpuscular volume (MCV), mean corpuscular haemoglobin $(\mathrm{MCH})$, and mean corpuscular haemoglobin concentration (MCHC) were measured on an Auto Haematology analyzer (MINDRAY BC-3200).

\subsection{Statistical analysis of data}

All values are reported as the mean \pm standard error of mean (S.E.M.). The values of the variables were analysed for statistically significant differences using the Student's T-test and Microsoft Excel 2010® Data Analysis tools. Differences were considered significant at $\mathrm{P}<0.05$.

\subsection{Results}

\subsection{Gas Chromatoraphy-Mass Spectrometry (GC-MS)} Analysis

The results of GC-MS analysis showing identified secondary metabolites present in $n$-hexane extract of $U$. chamae stems (UCSH) with their retention time, molecular formula, molecular weight and percentage composition are as presented in Table 1 [see supporting Document for spectra]. They include esters, terpenes, terpenoids, fatty acid, and sterols. The predominant components of UCSH are esters, including Isopropyl linoleate (14.3\%), Propyl (11Z)-11-octadecenoate (15.1\%), and Benzyl benzoate $(7.04 \%)$.

\subsection{Results of Genotoxicity Assays}

The results ofgenotoxicity assays of UCSH show the percent DNA fragmentations and the agarose gel electrophoresis of liver and testis tissues of mice of the groups $1-3$ are as shown in Table 2 and Figure 2. Smear formation on agarose gel indicates random DNA fragmentation, which was significantly lower in the liver of the mice treated with UCSH in comparison to the vehicle control group.

Table 1: Some Identified Secondary Metabolites Present in n-Hexane Extract of U. chamae Stems (UCSH)

\begin{tabular}{|c|c|c|c|c|}
\hline Ret. time (min) & Name & Molecular formula & Molecular weight $(\mathrm{g} / \mathrm{mol})$ & Area $(\%)$ \\
\hline 9.71 & $\alpha$-Santalene & $\mathrm{C}_{15} \mathrm{H}_{24}$ & 204.351 & 0.56 \\
\hline 9.79 & Benzene, 1,4-dimethoxy-2-methyl-5-isopropyl- & $\mathrm{C}_{12} \mathrm{H}_{18} \mathrm{O}_{2}$ & 194.270 & 0.74 \\
\hline 12.72 & $\beta$-maaliene & $\mathrm{C}_{15} \mathrm{H}_{24}$ & 204.351 & 1.40 \\
\hline 13.20 & Baldrinal & $\mathrm{C}_{12} \mathrm{H}_{10} \mathrm{O}_{4}$ & 218.205 & 1.15 \\
\hline 14.01 & Benzyl Benzoate & $\mathrm{C}_{14} \mathrm{H}_{12} \mathrm{O}_{2}$ & 212.244 & 7.04 \\
\hline 14.58 & 1H-Indole, 3-(3-methyl-2-butenyl)- & $\mathrm{C}_{13} \mathrm{H}_{15} \mathrm{~N}$ & 185.265 & 2.20 \\
\hline 19.08 & cis-vaccenic acid & $\mathrm{C}_{18} \mathrm{H}_{34} \mathrm{O}_{2}$ & 282.461 & 1.18 \\
\hline 22.08 & Isopropyl linoleate & $\mathrm{C}_{21} \mathrm{H}_{38} \mathrm{O}_{2}$ & 322.525 & 14.3 \\
\hline 22.18 & Propyl (11Z)-11-octadecenoate & $\mathrm{C}_{21} \mathrm{H}_{40} \mathrm{O}_{2}$ & 324.541 & 15.1 \\
\hline 27.81 & Squalene & $\mathrm{C}_{30} \mathrm{H}_{50}$ & 410.730 & 1.77 \\
\hline 29.56 & 28-Nor-17.beta.(H)-hopane & $\mathrm{C}_{29} \mathrm{H}_{50}$ & 398.707 & 1.37 \\
\hline 31.13 & Stigmasterol & $\mathrm{C}_{29} \mathrm{H}_{48} \mathrm{O}$ & 412.702 & 1.46 \\
\hline 31.54 & beta-Sitosterol & $\mathrm{C}_{29} \mathrm{H}_{50} \mathrm{O}$ & 414.707 & 1.46 \\
\hline 32.04 & Lupeol & $\mathrm{C}_{30} \mathrm{H}_{50} \mathrm{O}$ & 426.717 & 1.06 \\
\hline 33.98 & 4-Nitrophenyl laurate & $\mathrm{C}_{18} \mathrm{H}_{27} \mathrm{NO}_{4}$ & 321.417 & 1.44 \\
\hline
\end{tabular}




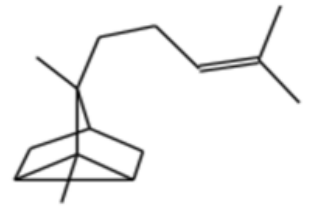

1<smiles>O=C(OCc1ccccc1)c1ccccc1</smiles>

5<smiles>CCCCCC/C=C\CCCCCC(=O)OCCC</smiles>

9<smiles>C=C(C)C1CCC2(C)CCC3(C)C(CCC4C3CCC3C4(C)CC[C@H](O)C3(C)C)C12</smiles>

13<smiles>COc1cc(C(C)C)c(OC)cc1C</smiles><smiles>CC1=C2C(CCC1C)CCC1(C)C2C1(C)C</smiles>

3<smiles>CC(C)=CCc1c[nH]c2ccccc12</smiles>

6<smiles>CCCCCC=CCCCCCCCC(=O)O</smiles>

7<smiles>CC(=O)OCc1cocc2c(C=O)ccc1-2</smiles>

4<smiles>CCCC/C=C/C/C=C/CCCCCCC(=O)OC(C)C</smiles>

8<smiles>CCC(CCC(C)C1CCC2C3CC=C4C[C@H](O)CCC4(C)C3CCC12C)C(C)C</smiles>

12

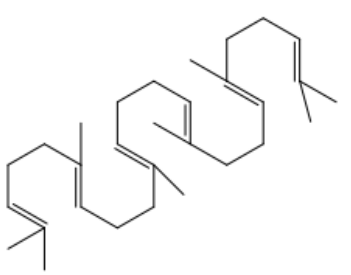

10<smiles>CCC(C=CC(C)C1CCC2C3CCC4C(C)CCC5(C)C4CCC3C5(C)C12C)C(C)C</smiles>

11

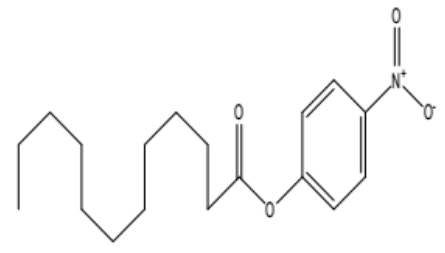

15

Figure 1: Structures of $\alpha$-Santalene (1), Benzene, 1,4-dimethoxy-2-methyl-5-isopropyl- (2) $\beta$-maaliene (3), Baldrinal (4), Benzyl Benzoate (5), 1H-Indole, 3-(3-methyl-2-butenyl)- (6), cis-Vaccenic acid (7), Isopropyl linoleate (8), Propyl (11Z)-11-octadecenoate (9), Squalene (10), Stigmasterol (11), beta.Sitosterol (12), Lupeol (13), 28-Nor-17.beta.(H)-hopane (14), and 4-Nitrophenyl laurate (15).

Table 2: DNA fragmentations of liver and testis tissues of the controls and UCSH treated mice

\begin{tabular}{c|lcc}
\hline & \multicolumn{1}{|c}{ Groups } & \multicolumn{2}{c}{ DNA fragmentation (\%) } \\
& & Liver & Testis \\
\hline 1. & Negative control & $56.07 \pm 0.57$ & $66.15 \pm 2.22$ \\
2. & Vehicle Control & $49.74 \pm 1.78$ & $60.52 \pm 8.49$ \\
3. & UCSH & $37.08 \pm 2.72^{*}$ & $54.72 \pm 0.82$ \\
\hline
\end{tabular}

Values are mean $(n=3) \pm$ S.E.M. Values with asterisk $(*)$ are significantly different $(p<0.05)$

\subsection{Results of determination of haematological parameters}

The effects of UCSH on the haematological indices consisting of white blood cell (WBC), hemoglobin (HB), packed cell volume (PCV), red blood cells (RBC), platelets (PLT), neutrophils (NEU), lymphocytes (LYMP), monocytes (MID), mean corpuscular hemoglobin (MCH), mean corpuscular hemoglobin concentration(MCHC) are as presented in Table 3. The results showed that WBC, RBC, PLT and LYMP were significantly higher while $\mathrm{NEU}, \mathrm{MCV}, \mathrm{MCH}$, and $\mathrm{MCHC}$ were significantly lower in UCSH treated mice than those of the vehicle control group.

\subsection{Discussion}

The safety condition of plants and other constituents used in the preparation of herbal remedies needs to be evaluated to be certified fit not just at the cellular phase but also at the genetic level.

It is as a result of this that we embarked on this study to evaluate the genotoxicity and haemato-modulatory effects of the n-hexane extract of $U$. chamae stems (UCSH) as well as to investigate the phytochemical contents of this non-polar extract.The phytochemical constituents of UCSH were determined by GC-MS technique. The separated compounds were identified based on comparison of their mass spectra with those in NIST Library as presented in Table 1 and Figure 1. The compounds include esters, including fatty acid esters (Isopropyl linoleate (14.3\%) and Propyl (11Z)-11-octadecenoate (15.1\%)); Benzyl benzoate (7.04\%); and 4Nitrophenyl laurate $(1.44 \%)$. 


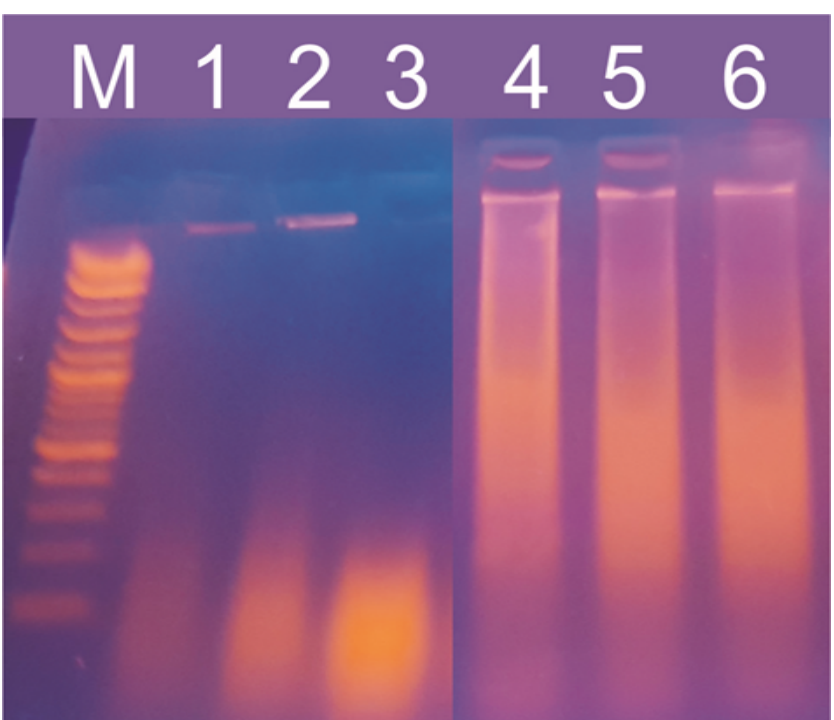

Figure 2: Agarose gel electrophoresis showing DNA fragmentation in hepatic and testis cells of controls and UCSH treated mice: Lane M; DNA molecular weight marker, Lane 1, 2, 3; livers of the negative, vehicle control and UCSH treated mice respectively; Lane 4, 5, 6; testis of the negative control, vehicle control and UCSH treated mice respectively.

Fatty acid esters are known for their wide Industrial and Pharmaceutical applications such as flavoring agents, additives, intermediates, binders, lubricants in food, cosmetic and plastic industries. Notwithstanding of their wide applications, they have raised safety concerns and have been subjected to many toxicity tests.

Benzyl benzoate, one of the ester identified is also useful as fragrance, solvent and preservative in cosmetics and pharmaceuticals. It is used as topical treatment for human scabies (Burns, 2010). Its vasodilating and spasmolytic effects have also been reported and its presence in many asthma and pertussis drugs (Brühne and Wright, 2007). A toxicity study has shown that when given in large doses to laboratory animals, benzyl benzoate can cause hyper excitation, loss of coordination, ataxia, convulsions, and respiratory paralysis (Shaikh, 2005).

Nitro compounds are rarely found in nature. However, Moses et al., (2013) identified a nitro compound; 1-Nitro-2-phenylethane as the major component $(63.2 \%)$ of the essential oil of $U$. chamae leaf. This may explain the presence of 4-Nitrophenyl laurate in the stem, as was discovered in this study.

The terpenes and terpenoids identified in the essential oils are $\alpha$ Santalene $(0.56 \%)$, baldrinal $(1.15 \%), \beta$-maaliene $(1.40 \%)$, squalene (1.77\%), lupeol (1.06\%) and 28-Nor-17.beta.(H)-hopane (1.37\%). $\alpha$ Santalene, baldrinal,and $\beta$-maaliene are used as flavour and fragrance agents while squalene, a triterpene is a biochemical precursor in the biosynthesis of steroids and has also shown promising medicinal potential.

Table 3: Effects of UCSH on the Haematological Indices of Mice

\begin{tabular}{|c|c|c|c|c|c|c|c|c|c|c|c|}
\hline Groups & $\begin{array}{c}\text { WBC } \\
\left(10^{6} / \mathrm{L}\right)\end{array}$ & HB (g/dL) & $\overline{\mathrm{PCV}(\%)}$ & $\overline{R B C}\left(10^{12} / \mathrm{L}\right)$ & $\begin{array}{c}\text { PLT } \\
\left(10^{12} / \mathrm{cmm}\right)\end{array}$ & $\begin{array}{l}\text { NEU } \\
(\%)\end{array}$ & $\overline{L Y M P(\%)}$ & $\begin{array}{l}\text { MID } \\
(\%)\end{array}$ & $\begin{array}{c}\mathrm{MCV} \\
(\mathrm{fL})\end{array}$ & MCH (pg/cell) & $\begin{array}{l}\mathrm{MCHC} \\
(\mathrm{g} / \mathrm{dL})\end{array}$ \\
\hline $\begin{array}{c}\text { Negative } \\
\text { control }\end{array}$ & $\begin{array}{c}2.2 \pm \\
0.03\end{array}$ & $\begin{array}{c}14.6 \\
\pm 0.17\end{array}$ & $\begin{array}{l}53 \pm \\
0.61\end{array}$ & $9.3 \pm 0.11$ & $949 \pm 10.9$ & $\begin{array}{l}44 \pm \\
0.51\end{array}$ & $\begin{array}{l}10 \pm \\
0.12\end{array}$ & $\begin{array}{l}46 \pm \\
0.53\end{array}$ & $\begin{array}{l}57 \pm \\
0.66\end{array}$ & $15.6 \pm 0.18$ & $\begin{array}{c}27.5 \\
\pm 0.32\end{array}$ \\
\hline $\begin{array}{l}\text { Vehicle } \\
\text { control }\end{array}$ & $\begin{array}{l}2.3 \pm \\
0.03\end{array}$ & $\begin{array}{c}14.3 \\
\pm 0.17\end{array}$ & $\begin{array}{c}52.1 \\
\pm 0.60\end{array}$ & $8.1 \pm 0.09$ & $938 \pm 10.8$ & $\begin{array}{l}45 \pm \\
0.51\end{array}$ & $9 \pm 0.10$ & $\begin{array}{l}46 \pm \\
0.53\end{array}$ & $\begin{array}{c}64.2 \\
\pm 0.74\end{array}$ & $17.7 \pm 0.20$ & $\begin{array}{c}27.4 \\
\pm 0.32\end{array}$ \\
\hline UCSH & $\begin{array}{l}2.5 \pm \\
0.03 *\end{array}$ & $14 \pm 0.16$ & $\begin{array}{c}53.2 \\
\pm 0.50\end{array}$ & $8.7 \pm 0.07 *$ & $\begin{array}{l}1020 \pm \\
11.78^{*}\end{array}$ & $\begin{array}{c}37 \pm \\
0.43^{*}\end{array}$ & $\begin{array}{c}18 \pm \\
0.21^{*}\end{array}$ & $\begin{array}{l}45 \pm \\
0.52\end{array}$ & $\begin{array}{c}61 \pm \\
0.70^{*}\end{array}$ & $16 \pm 0.18^{*}$ & $\begin{array}{l}26.3 \pm \\
0.30^{*}\end{array}$ \\
\hline
\end{tabular}

values are mean $(n=3) \pm$ S.E.M. Values with asterisk $(*)$ are significantly different $(p<0.05)$.

sterol present in UCSH has shown its potential to reduce benign prostatic

Squalene can effectively inhibit chemically induced skin, colon and lung tumorigenesis in rodents (Auffray, 2007). On the other hand, Lupeol, a triterpenoid with several medicinal potentials has been reported to show anti-inflammatory properties (Geetha and Varalakshmi, 2001), antiprotozoal, antimicrobial, antitumor and chemopreventive properties (Gallo and Sarachine, 2009).

Two sterols; stigmasterol (1.46\%) and beta-sitosterol (1.46\%), were identified in UCSH. Stigmasterol, a sterol also known as stigmasterin or Wulzen anti-stiffness factor with diverse pharmacological properties is involved in the synthesis of many hormones like progesterone, androgens, estrogens and corticoids. It has also been investigated for antiosteoarthritic, antihypercholestrolemic, cytotoxicity, antitumor, hypoglycaemic, antimutagenic, antioxidant, anti-inflammatory and CNS effects with positive results (Kaur et al., 2011). Beta-Sitosterol, another hyperplasia (BPH) (Wilt et al., 2000; Kim et al., 2012) and blood cholesterol levels (Rudkowskaet al., 2008). A study by Bouic et al. (1999) showed that beta-sitosterol increased some immuno-parameters in tested runners.

DNA fragmentation by DPA assay and agarose gel electrophoresis was performed to evaluate the genotoxicity of UCSH over a period of time exposure in hepatic and testis cells of male mice. Genetic toxicology is a multidisciplinary field of research involved in detecting compounds capable of causing DNA damage and/or protecting DNA, with the aim of understanding potential biological consequences and molecular mechanisms of genetic material (Uhl, et al., 2003). The DPA assay results as presented in Table 2 and Figure 2 showed that there were significant and marked reductions in DNA fragmentation in the hepatic and testis of 
the mice treated with the UCSH compared to the vehicle control group. The observed protective effect of UCSH on DNA could be attributed to some of the identified phytochemicals such as, squalene, lupeol and stigmasterol present in it. Squalene, Lupeol and Stigmasterol have been reported to possess anti-inflammatory, antitumour and chemopreventive properties (Geetha and Varalakshmi, 2001; Auffray, 2007; Gallo and Sarachine, 2009; and Kaur et al., 2011). Animal cells are continuously subjected to physiological and external influences which can give rise to cytotoxic, genotoxic and oxidative damage. These phytochemicals may exert beneficial effects and inhibit cellular injury and degeneration (Sarkar et al., 2008). This evidence may support the ethnomedicinal use of $U$. chamae stems for the treatment of cancer and inflammation.

The haematological assessment of UCSH showed that it induced changes in the haematological parameters of the treated mice as shown in Table 3. Significant reduction in neutrophils (NEU), mean corpuscular volume (MCV), mean corpuscular haemoglobin $(\mathrm{MCH})$, mean corpuscular haemoglobin concentration (MCHC) and significant increase in white blood cell (WBC), red blood cell (RBC) count, platelets (PLT) and lymphocytes (LYMP) were observed. The observed decrease in RBC in vehicle control $(8.1 \pm 0.09)$ and UCSH test groups $(8.7 \pm 0.07)$ are characteristic of anemic conditions and these reductions in RBC when compared with negative control $(9.3 \pm 0.11)$ indicates some level of effects on the RBC. The increase in the immune cells; WBC, PLT and LYMP, induced by the UCSH suggests favourable effects on the immune system of the mice.

\subsection{Conclusion}

Phytochemical compounds identified from n-hexane extract of U.Chamae stem (UCSH) include; squalene, lupeol, stigmasterol, beta-sitosterol, benzyl benzoate, cis vaccenic acid and have been reported to possess many pharmacological activities. The UCSH extract caused a reduction in DNA fragmentation in liver and testis tissues when compared with the DNA marker as qualitatively indicated in the agarose gel electrophoresis method which also suggests the protective role of UCSH treated group from diseases related to genetic damage. Haematological results showed that the extract contains phytochemicals capable of boosting the immune system.

\section{Acknowledgment}

The authors are grateful to the Central Research Laboratory, University of Lagos, for their support in the GC-MS analysis.

\section{Conflict of interest}

Authors declare no conflict of interest.

\section{Authors Contribution}

$\begin{array}{ll}\text { Manuscript design: } & \text { CSA, OAR, CHAB } \\ \text { Execution: } & \text { CSA, OAR, BO, AH, AF, TTE } \\ \text { Interpretation: } & \text { CSA, OAR, BO, TTE } \\ \text { Writing the manuscript: } & \text { CSA, OAR }\end{array}$

\section{Associated Content}

All supporting documents should be requested for at astjournals@gmail.com

\section{References}

Adelodun, V.O., Elusiyan, C.A., Olorunmola, F.O., Adewoyin, F.B., Omisore, N.O., Adepiti, A.O., Agbedahunsi, J.M. and Adewunmi, C.O., 2013. Evaluation of antitrypanosomal and anti-inflammatory activities of selected Nigerian medicinal plants in mice. Afr. J. Tradit. Complement. Altern. Med. 10(6), 469-476

Auffray, B., 2007. Protection against singlet oxygen, the main actor of sebum squalene peroxidation during sun exposure, using Commiphora myrrha essential oil. Int. J. Cosmet. Sci. 29, 23-29

Ayedoun, M.A., Moudachirou, M., Adeoti, B.S., Menut, C., Lamaty, G. and Bessiére, J., 1997. Aromatic Plants of Tropical West Africa. VII. Essential Oil of Leaf and Root Bark of Uvaria chamae P. Beauv. from Benin. J. Essential Oil Res., 11(1), 23-26

Bouic, P.J., Clark, A., Lamprecht, J., Freestone, M., Pool, E.J., Liebenberg, R.W., et al., 1999. The effects of $\beta$-sitosterol (BSS) and B-sitosterol glucoside (BSSG) mixture on selected immune parameters of marathon runners: inhibition of post marathon immune suppression and inflammation. Int. J. Sports Med. 20(4), 258-262

Brühne, F. and Wright, E., 2007. Benzyl Alcohol, Ullmann's Encyclopedia of Industrial Chemistry (7), 7

Burns, D.A., 2010, Diseases Caused by Arthropods and Other Noxious Animals, in Tony Burns; et al., Rook's Textbook of Dermatology, 2 (8), 38-41

Charles, D.H., William, L.L., Ken, H. and Jon, C., 1979. Uvarinol: a novel cytotoxic tribenzylated flavanone from Uvaria chamae. J. Org. Chem., 44(25), 4709-4710

Farnsworth, N.R., Akerele, O.O., Bingel, A.S., Soejarta, D.D. and Eno, Z., 1985. Medicinal plants in therapy. Bull. World Health Org., 63, 965-981

Feki, A., Saad, B.H., Jaballi, I., Magne, C., Boudawara, O., Zeghal, K.M., Hakim, A., Ali, B.Y. and Amara, B.I., 2015. Methyl thiophanateinduced toxicity in liver and kidney of adult rats: a biochemical, molecular and histopathological approach. Cell Mol. Biol. (Noisy le Grand), 63(2), 20-28

Gallo, M.B.C., and Sarachine, M.J., 2009. Biological activities of Lupeol. Int. J. Biomed. Pharm. Sci., 3(1), 46-66

Geetha, T., and Varalakshmi, P., 2001. Anti-inflammatory activity of lupeol and lupeol linoleate in rats. J. Ethnopharm., 76(1), 77-80

Gibb, R.K., Taylor, D.D., Wan, T., O'Connor, D.M., Doering, D.L., and Gerçel-Taylor, C., 1997. Apoptosis as a measure of chemosensitivity to cisplatin and taxol therapy in ovarian cancer cell lines. Gynecol Oncol. 65(1), 13-22

Kaur, N., Chaudhary, J., Jain, A. and Kishore, L., 2011. Stigmasterol: A Comprehensive Review. Int. J. Pharm. Sci. Res., 2(9), 2259-2265

Kim, T.H., Lim, H.J., Kim, M.S. and Lee, M.S., 2012. Dietary supplements for benign prostatic hyperplasia: An overview of systematic reviews. Maturitas, 73(3), 180-185

Kone, M., Toure, A., Ouattara, K. and Coulibaly, A., 2015. Phytochemical Composition, Antioxidant and Antibacterial Activities of Root of Uvaria chamae P. Beauv. (Annonaceae) used in Treatment of Dysentery in North of Côte d'Ivoire. Int. J. Pharmacog. Phytochem. Res., 7(6), 1047-1053 
Moses, O.S., Olowu, R.A., Noura S.D. and William, N.S., 2013. 1-Nitro2-phenylethane dominates the chemical composition of the leaf essential oil of Uvaria chamae from Badagry, Nigeria. Am. J. Essential Oils Nat. Prod., 1(1), 48-50

OECD, 2008. Guidelines for the Testing of Chemicals; Test No. 425: Acute Oral Toxicity - Up-and-Down-Procedure (UDP).

Oguntimein, B.O., Ekundayo, O.O., Laakso, I. and Hiltunen, R., 1989. Volatile Constituents of Uvaria chamae Leaves and Root Bark. Planta Medica. 55(3), 312-313

Okwu, D. and Iroabuchi, F., 2009. Phytochemical Composition and Biological Activities of Uvaria chamae and Clerodendoron splendens. E-Journal Chem., 6(2), 553-560

Okwuosa, O.M., Chukwura, E.I., Chukwuma, G.O., Okwuosa, C.N., Enweani, I.B., Agbakoba, N.R., Chukwuma, C.M., Manafa, P.O., and Umedum, C.U., 2012. Phytochemical and antifungal activities of Uvaria. chamae leaves and roots, Spondias mombin leaves and bark and Combretum racemosum leaves. Afr. J. Med. Sci., 41, 99-103

Oluremi, B.B., Osungunna, M.O., and Omafuma, O.O., 2010. Comparative assessment of antibacterial activity of Uvaria chamae parts. Afr. J. Microbiol. Res. 4(13), 1391-1394

Rudkowska, I., AbuMweis, S.S., Nicolle, C., and Jones, P.J., 2008. Cholesterol-lowering efficacy of plant sterols in low-fat yogurt consumed as a snack or with a meal. J. Am. Coll. Nutr., 27(5), 588595

Sarkar, D., Sharma, A. and Talukder, G., 2008. Plant extracts as modulators of genotoxic effects. The Botan. Rev., 62(4), 275-300.

Shaikh, J., 2005. Benzyl Benzoate, in Philip Wexler, Encyclopedia of Toxicology, Elsevier (1), 264-265

Thierry, A.C., Joachim, D.G., Kpoviessi, S.D.S., Accrombessi, G.C., Moudachirou, M. and Gbeassor, M., 2012.Antihemolytic Properties of Extracts of Six Plants Used in the Traditional Treatment of Sickle Cell Disease in Benin. J. Appl. Pharm. Sci., 2(3), 8-13

Tognolini, M., Barocelli, E., Ballabeni, V., Bruni, R., Bianch, A.,Chiavarini, M., and Impecciatore, M., 2006. Comparative screening of plant essential oils: Phenylpropanoid moiety as basic core for antiplatelet activity. Life Sci., 78, 1419-1432

Uhl M, Plewa M.J, Majer B.J, Knasmüller S., 2003. Basic principles of genetic toxicology with an emphasis on plant bioassays In: Maluszynska J, Plewa M, editors. Bioassays in Plant Cells for Improvement of Ecosystem and Human Health. Katowice: Wydawnictvo Uniwersytetu Ślaskiego, pp. 11-30

Uwaifo, A.O. and Bababunmi, E.A., 1984. Liver carcinogenesis in tropical Africa. IARC Sci Publ. 63, 59-88

Wilt, T., Ishani, A., MacDonald, R., Stark, G., Mulrow, C. and Lau, J., 2000. Beta-sitosterols for benign prostatic hyperplasia. The Cochrane Libr. 2, CD001043 